\title{
FAMILY EMPOWERMENT MODEL IN THE PREVENTION OF TYPE II DIABETES MELLITUS AT KALIPARE, MALANG, EAST JAVA
}

\author{
Fiashriel Lundy
}

School of Health Polytechnics, Ministry of Health, Semarang, Central Java

\begin{abstract}
Background: Diabetes mellitus (DM) is a "lifelong disease". To reduce the risk of complications and prevent the DM, a program for patient and family in managing type II diabetes mellitus (Type 2 DM) is needed. This study aimed to determine the family empowerment model in the prevention of Type 2 DM in Kalipare, Malang, East Java.

Subjects and Method: This was a quasi experiment conducted in Kalipare, Malang, East Java. A sample of 30 household heads with DM was selected for this study and divided into 3 groups: (1) 10 household heads in the empowerment model 1 ; (2) 10 household heads in the empowerment model 2; and (3) 10 household heads in the control group. The dependent variables were knowledge and family coping. The independent variable (intervention) was model of family empowerment in Type $2 \mathrm{DM}$ prevention. Family coping was measured by Family Coping Index (FCI). The other data were collected by a questionnaire. The data were analyzed by One Way Anova and post-hoc test.

Results: Family empowerment model 2 had the highest score in knowledge (Mean= $59.6 ; \mathrm{p}=0.023)$ and family coping (Mean $=28.4 ; \mathrm{p}=0.041)$ of all three study groups and the differences were all statistically significant.

Conclusion: Family empowerment model 2 is effective to improve knowledge and family coping in the prevention of Type $2 \mathrm{DM}$.
\end{abstract}

Keywords: family empowerment, model, prevention, diabetes mellitus.

Correspondence:

Fiashriel Lundy. School of Health Polytechnics, Ministry of Health, Semarang, Central Java. Email: fiashriellundy@yahoo.com. Mobile: 0811367446.

The $6^{\text {th }}$ International Conference on Public Health

Best Western Premier Hotel, Solo, Indonesia, October 23-24, $2019 \mid 79$ https://doi.org/10.26911/the6thicph.01.56 